вимогою до ефективної організації самостійної навчально-пізнавальної діяльності студентів у здоров'язбережувальній освітній системі є забезпечення індивідуального підходу як умови якості результатів навчання і підгрунтя формування творчої особистості майбутнього вчителя на засадах забезпечення його фізичного, психічного і духовного здоров'я.

У зв'язку з цим логічним є більш докладний аналіз методів і засобів урахування інших індивідуально-психологічних особливостей студентів у процесі їхньої самостійної роботи, тому перспективою подальших наукових пошуків може бути дослідження рівня впливу сформованості інтелектуальних умінь, елементів розумової культури, мотиваційних настанов на результативність самостійної роботи студентів фізико-математичних факультетів.

\title{
Література
}

1. Афонін А. П. Стратегічні принципи в системі організації здоров'язберігаючої освіти у школі та ВНЗ / А. П. Афонін // Педагогіка вищої та середньої школи : зб. наук. праць / за ред. З. П. Бакум: Вип. 34. - Кривий Ріг : КПУ КНУ, 2012.-С. 216-220. 2. Дурас Т. Формування навичок здорового способу життя / Тетяна Дурас // Сучасна школа України. - 2012. - № 5(545). - С. 56-58. 3. Лавров Е. А. Створення електронного курсу з адаптацією до стилів мислення / Е. А. Лавров, Н. А. Барченко // Наука і методика. - 2009. - № 17. - С. 41-45. 4. Самоукина Н. В. Психология и методика профессиональной деятельности / Н. В. Самоукина. - М. : Ассоциация авторов и издателей «ТАНДЕМ», издательство ЭКМОС, 2000. - 384 с. 5. Теорія і практика організації самостійної роботи студентів вищих навчальних закладів : [монографія]/ ред. проф. О. А. Коновала. - Кривий Ріг: Кирєєвського, 2012. $-380 \mathrm{c}$.

УДК 378.016:7.071.2+7.01

Тетяна Фурдак

\section{ВИКОРИСТАННЯ СУМІЖНИХ ВИДІВ МИСТЕЦТВА ЯК ВАЖЛИВИЙ СКЛАДНИК НАВЧАННЯ ДИРИГЕНТА У ВНЗ}

Фурдак Т. Д. Використання суміжних видів мистецтва як важливий складник навчання диригента у ВНЗ.

У статті розкрито питання використання суміжних видів мистецтва у процесі навчання майбутнього вчителя музики, зокрема, на заняттях 3 диригування, та доведено роль синтезу хореографічного та акторського мистецтва у цьому процесі. Зазначено, що естетична спільність цих видів мистецтв має сутнісні подібності.

Ключові слова: суміжні види мистецтва, мистецтво диригента, хореографічне мистецтво, акторське мистецтво, культуротворчий вплив.

Фурдак Т. Д. Использование смежных видов искусства как важная составляющая обучения дирижера в вузе.

В статье раскрыты вопросы использования смежных видов искусства в процессе обучения будущего учителя музыки, в частности, на занятиях по дирижированию, доказана роль синтеза хореографического и актерского искусства в этом процессе. Указано, что эстетическая общность этих видов искусств имеет существенные сходства.

Ключевые слова: смежные виды искусства, искусство дирижера, хореографическое искусство, актерское искусство, культуротворческое влияние. 
Furdak T. D. Applying related arts as an important part of training conductors at universities.

The article highlights issues as for using related arts in teaching future music teachers, in particular at classes in conducting art. The author proves the role of synthesis of choreographic and dramatic art in this process. The author also states that aesthetic community of these arts has significant similarities.

Key words: related arts, conductor's skills, choreographic art, the art of acting, culture and creative influence.

Важливою базою створення теорії диригентського мистецтва є література про видатних диригентів-симфоністів Д. Бортнянськоого, М. Березовського, А. Веделя, Г. Караяна, О. Кошицю, Я. Калішевського, С. Кусевіцького, Е. Мравінського, М. Ростроповіча, Є. Свєтланова, К. Стеценка, Ю. Темірканова та ін. Це дослідження або статті, нариси музикантів-сучасників, видатних маестро. Тут можна відзначити вітчизняних і зарубіжних авторів, таких, як: В. Богданов-Березовський, Р. Косачова, Л. Крилова, Л. Міхєєва, Т. Островська, П. Робінсон, В. Фомін, та ін.

Незважаючи на відносно численні публікації 3 питань диригування, його теоретичне освоєння має ще безліч практичних досягнень.

Метою статті є розкриття питання використання суміжних видів мистецтва у процесі навчання майбутнього вчителя музики, зокрема, на заняттях 3 диригування у вищому навчальному закладі та доведенні ролі синтезу хореографічного та акторського мистецтва у цьому процесі.

Над розробкою проблем хорового диригування працювали такі майстри хорового мистецтва, як Л. Андреєва, Г. Дмитревський, О. Сгоров, С. Казачков, М. Канерштейн, К. Птиця, П. Чесноков та ін. Важливе місце вітчизняна школа диригування посіла завдяки високопрофесійній яскравій діяльності як видатних українських маестро, так і знаних митців, виконавська творчість яких була тісно пов'язана 3 Україною. Зазначимо імена В. Сука, Л. Штейнберга, А. Пазовського, В. Бердяєва, В. Дранишникова, М. Малька, М. Колесси, Н. Рахліна, В. Пірадова, К. Сімеонова, В. Тольби, І. Зака, Я. Карасика, С. Турчака, О. Рябова, І. Лацанича та ін.

Із професійних диригентських якостей дослідники називають володіння системою диригентських жестів, розвинений вокальний слух, виражену комунікабельність, педагогічну майстерність. Славетні традиції старшого покоління українських маестро приблизно з другої половини минулого століття й дотепер продовжує та примножує плеяда видатних вітчизняних диригентів, серед яких Є. Дущенко, I. Блажков, Ф. Глущенко, В. Кожухар, В. Гнєдаш, Р. Кофман, В. Здоренко. На їх думку, склад професійно важливих якостей майбутнього диригента-вчителя музики зумовлений багатофункціональним характером його діяльності, яка включає функції виконавця, педагога, керівника хорового колективу. Він повинен володіти навичками всебічного аналізу хорової партитури, розумінням їі структури, особливостями форми, виразних засобів, здатністю глибоко та змістовно інтерпретувати музичний твір. Ці якості та здібності необхідні диригентові насамперед задля розуміння музичного твору, створення музично-художнього образу. Саме музичні якості диригента, його музично-виконавська культура забезпечують високий художній рівень виконання.

Але одного визнання вирішальної ролі спеціальних музичних якостей недостатньо. На нашу думку, необхідне використання суміжних видів мистецтв, наявність яких, крім музичних, $€$ необхідною умовою професійної діяльності диригента. 
Невербальне спілкування людей за допомогою рухів і жестів формувалося й розвивалося ще з часів зародження людства. Звичайно, в житті кожної людини почуте слово є головним засобом спілкування між собою. Але думка, слово завжди пов'язані 3 рухом, жестом.

Мистецтво диригента - це здатність відчувати кожного з виконавців, причому це зв'язок двосторонній - диригент - артист - диригент. Не тільки важливо, щоб на тебе дивилися, а важливо, щоб ти бачив і відчував кожного, відчував його емоційний стан і якоюсь мірою підкорювався йому.

На нашу думку, для встановлення такого тісного творчого контакту, для продуктивності спільної роботи диригент повинен володіти суміжними видами мистецтва, що повинно стати основною умовою здійснення комплексного підходу в навчанні, збагатити й поглибити знання 3 предмету, розширити загально-естетичний кругозір майбутнього вчителя музики.

Інтеграція сучасної освіти відбувається, на нашу думку, за кількома напрямками й на різних рівнях: предметному та міжпредметному.

Міжпредметні зв'язки - традиційна педагогічна проблема, що зазвучала поновому в сучасних умовах. Вищий навчальний заклад не може обмежуватися лише засвоєнням студентами певного обсягу знань, фактів - перед ним стоїть завдання: навчити майбутніх учителів самостійно поповнювати свої знання, орієнтуватися в стрімкому потоці інформації. У вищому навчальному закладі повинні міцно формуватися вміння аналізувати, порівнювати, узагальнювати - все те, що стане в нагоді майбутнім учителям у їх майбутній професійній діяльності.

Проблемі міжпредмених зв'язків приділялась увага багатьох вітчизняних i зарубіжних науковців (М. Антонов, М. Данилов, І. Огородников, О. Шмідт, Г. Юрков та ін.).

Сучасний стан дослідження цієї проблеми висвітлений у працях І.Звєрєва, Л. Кулагіна, В. Максимової, О. Савченко, М. Сорокіна, В. Федорової та інших науковців. Зокрема, проблема комплексного використання суміжних видів мистецтв, що необхідно майбутнім вчителям мистецьких дисциплін, а саме у процесі занять 3 диригування у вищому навчальному закладі на сьогодні малодосліджена.

У багатьох працях науковців залучення на заняття іншого виду мистецтва подається через принцип наочності, що позбавляє твір як естетичну модель світу глибинних знань про його особливості.

Ми підтримуємо думку науковців, які довели, що передача різноманітних знань 3 теорії й історії мистецтва $є$ необхідною, оскільки без них неможливе оволодіння багатовіковою художньою спадщиною народу (В. Абрамян, І. Зязюн, А. Капська, Л. Масол, Н. Миропольська, О. Рудницька, Г. Сагач, С. Черепанова).

Нині дедалі глибше усвідомлюється важливість комплексного підходу до використання культуротворчого впливу різних видів мистецтв у процесі вивчення музичних дисциплін.

Так, зокрема, проблемам естетичного виховання за допомогою різних мистецтв присвячені праці О. Бандури, Н. Волошиної, О. Мазуркевича, Л. Мірошниченко, Є. Пасічника, Г. Шевченко. Учені довели, що синтетичний характер художньої діяльності зумовлює таку ж єдність освіти, виховання i навчання, під час якої формуються художньо-творчі здібності особистості.

У своїй книзі «Бесіди про диригентське ремесло» Б. Хайкін зазначає, що «Диригент повинен добре знати всі суміжні мистецтва. Необхідно, щоб його майстерність, вміння виходили далеко за межі власне диригування. У своєму рідному музичному мистецтві йому потрібно бути гранично озброєним» [6, с. 15]. 
На нашу думку, серед ряду суміжних видів мистецтв (живопис, графіка, скульптура, театр, кіно), які впливають на різні сфери сприймання й створюють додаткові можливості для художнього розвитку майбутнього вчителя музики на заняттях із диригування осторонь залишились хореографія (пантоміма) та акторське мистецтво.

Виявляючи подібність виразних рухів та акторської майстерності, можна виділити їх загальні властивості, що дозволяють краще зрозуміти природу, сутність i специфіку досліджуваного явища - мистецтва диригування.

Правомірність зіставлення мистецтва диригування 3 пантомімою (хореографією) та акторським мистецтвом обумовлена тим, що останні належать до виконавського мистецтва, що $\epsilon$ посередником між творчістю постановника й сприйняттям публіки. Подібні найважливіші характеристики мистецтва диригування, пантоміми та акторського мистецтва об'єднують їх за принципом й дозволяють розглядати як явища одного ряду.

Проблему подібності диригування та хореографії вивчали багато відомих діячів мистецтва минулої епохи. У «Бесідах про музику» Е. Ансерме наводиться думка у вигляді питання швейцарському диригентові з боку його співрозмовника - філософа Ж.-К. Піге. «Багато хто вважає, - звертається він до Ансерме, - і часто говорять, що управління оркестром або хором схоже на танець» [1, с. 91]. Говориться про ритмічність жестикуляції рук і гнучку пластику диригента. Але вірно й те, що «схоже на танець» і сам танець - не одне й те ж. І. Мусін також зазначав, що диригування в якомусь відношенні наближається до хореографії [4, с. 109].

Естетична спільність мистецтва диригування та хореографічного мистецтва має сутнісні подібності. Це стосується тісного зв'язку музики та рухів. На думку Б. Асафьева, музична інтонація тісно пов'язана не тільки зі словом, але й з танцем, 3 мімікою та пантомімою людського тіла. Фактично про це ж писав і Г. Нейгауз, відзначаючи, що в музиці «завжди підсвідомо відчувається рух, жест («робота м'язів»), хореографічний початок» [5, с. 44].

Танець, як i диригування, ніколи не існує поза музикою. Правда, джерелом диригентських художньо-образних рухів є музика, яка подумки звучить у свідомості диригента; джерелом хореографічних рухів є музика, яка і породжує танцювальнопластичні образи. Більш того, диригент випереджаючими діями (ауфтакти) керує музикою, що виконується хором або оркестром; танцюрист - підпорядковується їй, синхронізуючи свої виразні рухи з музичним процесом.

Танець і музику, з одного боку, об'єднує спільна метроритмічна організація; 3 іншого - здатність найсильнішого і безпосереднього емоційного впливу на глядачів, слухачів. Це пояснюється тим, що між танцем і музикою існує історично зумовлений генетичний зв'язок. Тому, коли на певному історичному етапі постало питання про виразно-художнє керівництво хоровим виконавством, то пластичні рухи хореографії були інтуїтивно затребувані в якості основного виразного засобу майбутнього мистецтва диригування.

Отже, можна констатувати: сутнісна спільність диригування та хореографії проявляється в їх можливостях пластично виражати музику. Жест в широкому сенсі слова притаманний, з одного боку, танцю, хореографії взагалі, з іншого - мистецтву диригування. Таким чином, у диригуванні та хореографії $\epsilon$ спільні виразні засоби, а головне - сам художній матеріал у вигляді тілесної пластики. Іншими словами, мистецтво диригування засноване на художньому матеріалі (пластика) та виразних засобах (рухах, жестах) міміки, пластичних видів мистецтв, насамперед хореографії.

Якщо музика є часовий процес, то диригування, хореографія - реальний рух. Саме цей факт спонукав хорового диригента К. Ольхова написати наступне, що 
танець дозволяє побачити принципову можливість відображення «потоку звуків»у «потоці рухів». Навпаки, за характером рухів можна хоча б приблизно уявити відповідну їм музику, що так важливо в диригентсько-виконавському мистецтві.

Аналізуючи мистецтво диригування та хореографію, можна зазначити таке: 1. Основним джерелом диригентських та хореографічних рухів $\epsilon$ музика. 2. Мистецтво диригування засноване на художньому матеріалі (пластиці) та художніх засобах пластичних видів мистецтв, а саме хореографії. 3. Мистецтво диригування $\epsilon$ відносно точна модель музики з боку ії змісту та форми; танець $є$ вільним, зразковим художньо-образним і структурно-композиційним аналогом музики.

Не менш важливе так зване мистецтво перевтілення творчого стану артиста головне, що ріднить професії диригента й актора. Спільність мистецтва диригування та акторського мистецтва полягає й у тому, що вони проявляють себе як «мистецтво внутрішньої та зовнішньої дії» (К. Станіславський).

I диригент, i актор можуть не тільки внутрішньо відчувати i переживати відповідний образ, але й зовні втілювати його. Єдність процесу переживання й втілення художнього образу є суттю системи Станіславського. Художній образ, на думку М. Кагана, виступає в акторському мистецтві як «виразне перевтілення» [2, с. 59]. «Психологічний грим»- так називав Ф. Шаляпін мистецтво перевтілення актора. Така ситуація й у диригентської професії, де психологічним механізмом створення міміка-пластичного образу виконуваної музики також виявляється мистецтво перевтілення, яскравий артистизм диригента, заснований на акторському таланті й технічній майстерності.

У художній системі Станіславського є два принципи акторської творчості, які в тій чи іншій мірі використовуються й у диригуванні- «мистецтво переживання» $\mathrm{i}$ «мистецтво подання». «Мистецтво переживання» вимагає від диригента навмисного відтворення емоцій, що диктуються музикою. Але, як стверджував К. Станіславський, пристрасті не піддаються ні наказом, ні насильству. Тільки натхнення - стан найвищого творчого піднесення - дає можливість свідомо відтворювати художні емоції, а завдячуючи самій музиці, це максимально тому сприяє.

Результатом акторського перевтілення $є$ видимий образ літературного героя. У диригентському виконавстві результатом перевтілення артиста $\epsilon$ конкретне чутне звучання - музичний образ. Однак специфіка колективного виконавства вимагає від диригента не лише внутрішнього, а й зовнішнього перевтілення, оскільки проміжним результатом його діяльності має бути «видимий» музичний образ, який втілюється засобами емоційного впливу на хор або оркестр.

Проблема сценічного артистизму та творчого перевтілення - одна 3 головних у мистецтві диригування, й у цьому виявляється спільність диригентської та акторської професій. Художні емоції, як диригента, так i актора носять усвідомлений i контрольований характер, що зумовлює створення зовнішнього міміка-пластичного образу завдяки внутрішній психотехніці артиста. Творче перевтілення й у диригентському, й у акторському мистецтві здійснюється на основі художньої уяви, чуттєвого переживання, «вживання» в образ, який виконується.

Отже, кожний вид мистецтва - це окрема система, в якій можна виділити види, жанри, зображувально-виражальні засоби, стилі.

На основі аналізу вищезгаданих джерел, досвіду викладачів вищих навчальних закладів за профільним навчанням мистецьких дисциплін, можна засвідчити, що синтез суміжних мистецтв, а саме диригентського, хореографічного та акторського мистецтва мають сутнісні подібності. Синтез цих видів мистецтв- не будь-яка довільна взаємодія, а така, в результаті якої розв'язуються суперечності між 
взаємодіючими мистецтвами й народжується якісно нове мистецтво, відмінне від тих, що вступили у взаємодію.

Здатність до синтезування сприяє систематизації дійсності та уявлень про неї, знаходячи вияв у найрізноманітніших видах людської діяльності. Феномен синтезу мистецтв реалізується в єдиному художньому образі або системі образів, що об'єднані єдністю задуму, стилю, виконання, але створені за законами різних мистецтв.

\section{Література}

1. Ансерме Е. Беседы о музыке / Эрнэст Ансэрмэ; [пер. с франц.]. - М. : Музыка, 1985. - 104 с. 2. Каган М. Морфология искусства / Моисей Семенович Каган. - М. : Искусство, 1972. - 441 с. 3. Макаренко Г. Типологія творчого процесу диригента / Г. Макаренко // Культура і сучасність: Альманах державної академії керівних кадрів культури і мистецтв № 2. - Київ, 2004. 4. Мусін І. Язык дирижерского жеста / Илья Александрович Мусин. - М. : Музыка, 2007. - 256 с. 5. Нейгауз Г. Об искусстве фортепианной игры / Генрих Густавович Нейгауз; [метод. пособие]. - Л. : Музыка, 1958. - 202 с. 6. Хайкин Б. Беседы о дирижерском ремесле / Борис Эммануилович Хайкин. - Л. : Советский композитор, 1984. - 240 с.

УДК $378.147+159.9$

Тетяна Шепеленко

\section{КОМУНІКАТИВНИЙ СКЛАДНИК ПРОФЕСІЙНОЇ КОМПЕТЕНТНОСТІ МАЙБУТНІХ ФАХІВЦІВ ЕКОНОМІЧНОГО ПРОФІЛЮ}

Шепеленко Т. Л. Комунікативний складник професійної компетентності майбутніх фахівців економічного профілю.

У статті розкрито сутність комунікативного складника професійної компетентності майбутніх фахівців 3 економіки, здійснено порівняльний аналіз базових понять, розглянуто структурні компоненти комунікативної компетентності, визначено педагогічні умови ефективного формування комунікативної компетентності.

Ключові слова: комунікація, компетентність, професійна компетентність, комунікативна компетентність, структура комунікативної компетентності, педагогічні умови.

Шепеленко Т. Л. Коммуникативная составляющая профессиональной компетентности будущих специалистов экономического профиля.

В статье раскрыта сущность коммуникативной составляющей профессиональной компетентности будущих специалистов экономического профиля, рассмотрены ее структурные компоненты, определены педагогические условия эффективного формирования коммуникативной компетентности.

Ключевые слова: коммуникация, компетентность, профессиональная компетентность, коммуникативная компетентность, структура коммуникативной компетентности, педагогические условия.

Shepelenko T. L. Communicative component of professional competence of future economists.

The article reveals the essence of the communicative component of professional competence of future economists. The author describes its structural components, defines pedagogical conditions of effective forming communicative competence.

Key words: communication, competence, professional competence, communicative 